\title{
PENGARUH PEMBELAJARAN DARING DAN LURING TERHADAP MINAT BELAJAR MAHASISWA PADA MASA PANDEMI COVID-19
}

\author{
Silfia masrurotul laili ${ }^{1}$, Dassucik $^{2}$, Irma Noervadila ${ }^{3}$ \\ ${ }^{1,2,3}$ STKIP PGRI Situbondo, Indonesia \\ Email: silfiamasruro12@gmail.com
}

Received: Augustus 25, 2021 Revised: Augustus 29,2021 Accepted: Sept 4, 2021

\begin{abstract}
ABSTRAK
Dilihat dari masa pandemi saat ini minat belajar mahasiswa sepertinya kurang baik. Maka tujuan dari penelitian adalah untuk mengetahui apakah pembelajaran daring dan luring berpengaruh terhadap minat belajar mahasiswa pada masa pandemi covid-19. Penelitian ini menggunakan metode ex-post facto. Metode pengumpulan data menggunakan observasi, angket dan dokumentasi. Dari hasil penelitian yang diperoleh menggunakan rumus chi square menghasilkan sebesar 1,6566 yang apabila dikonsultasikan dengan $r_{\text {tabel }}$ dengan $(\mathrm{db})=1$ pada tabel taraf signifikansi $5 \%=3,841$. Maka dari hasil perhitungan tersebut menunjukkan harga $\mathrm{r}_{\text {hitung }} 1,6566<$ harga $\mathrm{r}_{\text {tabel. }}$. Untuk hasil analisis minor pertama untuk uji signifikansi antara pembelajaran daring terhadap minat belajar mahasiswa yang diperoleh hasil $r_{\text {hitung }} 0,0232$ dan taraf signifikansi $5 \%=3,841$ artinya harga $r_{\text {hitung }}$ $<$ harga $r_{\text {tabel. }}$ Untuk hasil analisis minor kedua untuk uji signifikansi pembelajaran luring terhadap minat belajar mahasiswa yang diperoleh hasil $\mathbf{r}_{\text {hitung }}$ 14,2734 dan taraf signifikansi $5 \%=3,841$ artinya harga $r_{\text {hitung }}>$ harga $r_{\text {tabel. }}$
\end{abstract}

Kata kunci: Pandemi covid-19, Pembelajaran Daring dan Luring, Minat Belajar

\begin{abstract}
Judging from the current pandemic, student interest in learning seems to be not good. So the purpose of the study was to find out whether online and offline learning had an effect on student interest in learning during the covid-19 pandemic. This study uses the ex-post facto method. Methods of data collection using observation, questionnaires and documentation. From the research results obtained using the chi square formula, the result is 1.6566 which when consulted with rtable with $(\mathrm{db})=1$ in the table of $5 \%$ significance level $=3.841$. So from the results of these calculations show the price of rcount $1.6566<$ rtable price. For the results of the first minor analysis for the significance test between online learning and student interest in learning, the results obtained rcount 0.0232 and a significance level of $5 \%=3.841$, meaning that the price of rcount $<$ rtable price. For the results of the second minor analysis
\end{abstract}


to test the significance of offline learning on student interest in learning, the results obtained are $r$ count 14.2734 and a significance level of $5 \%=3.841$, meaning that the price of $r$ count $>r$ table price.

Keywords: Covid-19 pandemic, Online and Offline Learning, Interest in Learning

\section{PENDAHULUAN}

Pembelajaran juga diartikan sebagai proses memberikan bimbingan atau bantuan kepada mahasiswa dalam melakukan proses belajar (Pane \& Dasopang, 2017). Pembelajaran merupakan interaksi yang dilakukan bersifat edukatif yang berarti segala interaksi yang dilakukan memiliki tujuan, menambah wawasan dan meningkatkan kecerdasan bagi mahasiswa (Sijabat et al., 2020).

Pandemi covid-19 adalah penyakit menular yang disebabkan oleh coronavirus yang baru ditemukan. Sebagian besar orang yang terinfeksi virus covid-19 akan mengalami penyakit pernapasan ringan hingga sedang dan sembuh tanpa memerlukan perawatan khusus. yang lebih tua, dan mereka yang memiliki masalah medis seperti penyakit berat seperti diabetes, penyakit pernapasan kronis, dan kanker lebih mungkin mengembangkan penyakit serius (Waruwu, 2020).

Salah satu cara menanggulanginya adalah dengan menggunakan pembelajaran daring merupakan sistem pembelajaran yang tidak berlangsung satu ruangan dan tidak ada interaksi tatap muka secara langsung antara pengajar dan pembelajar (Setyaningsih, 2020). Pembelajaran daring atau yang lebih dikenal dengan online learning merupakan pembelajaran yang dilakukan dengan bantuan internet ataupun jaringan melaui aplikasi yang sudah tersedia.

Menurut Syarifudin, (2020) menjelaskan bahwa pembelajaran daring adalah bentuk pembelajaran yang mampu menjadikan mahasiswa mandiri tidak bergantung pada orang lain. Hal ini karena mahasiswa akan fokus pada gawai untuk menyelasaikan tugas ataupun mengikuti diskusi yang sedang berlangsung. Pembelajaran daring dilakukan menggunakan aplikasi yang dapat diakses dengan jaringan secara keseluruhan mahasiswa puas dengan pembelajaran yang fleksibel. Dengan pembelajaran daring, dosen memberikan pembelajaran melalui kelaskelas virtual seperti google classroom, edlink, zoom cloud, google meet dan lain sebagainya yang dapat diakses dimanapun dan kapanpun tidak terikat ruang dan waktu (Susanti, 2020). 
Luring menurut Malyana dalam Sunendar, dkk (2020) disebutkan bahwa istilah luring adalah luar jaringan atau terputus dari jaringan komputer. Misalnya belajar melalui buku pegangan mahasiswa atau pertemuan langsung. Pembelajaran luring disini bisa menggunakan dengan metode cooperativ learning. Pembelajaran kooperatif merupakan model pembelajaran dengan menggunakan sistem pengelompokan tim kecil, yaitu antara empat sampai enam orang yang mempunyai latar belakang kemampuan akademik, jenis kelamin, ras, atau suku yang berbeda (heterogen) (Jaelani, 2015).

Menurut Rofiq, (2010) metode cooperativ learning adalah kegiatan belajar mengajar dalam kelompok kecil, mahasiswa belajar dan bekerjasama untu sampai pada pengalaman belajar yang optimal baik pengalaman individu maupun kolompok. Minat pada dasaranya merupakan penerimaan akan suatu hubungan antara diri sendiri dengan sesuatu diluar diri, semakin kuat atau dekat hubungan tersebut, maka semakin besar minatnya (Lestari, 2015). Menurut Munirah et al., (2018) belajar merupakan proses penting bagi perubahan perilaku seseorang dan mencakup segala sesuatu yang dipikirkan dan dikerjakan. Minat Belajar adalah salah satu faktor internal dari aspek psikologis yang sangat berpengaruh dan memegang peranan penting dalam proses kegiatan belajar dan perkembangan belajar mahasiswa serta keberhasilan mahasiswa dalam belajar. (Ah et al., 2019). Pengaruh minat terhadap suatu kegiatan belajar sangat besar, karena apabila suatu kegiatan belajar tidak sesuai dengan minat maka hasilnya akan dicapai tidak maksimal, karena tidak ada perasaan tertarik, perhatian, perasaan senang dan usaha untuk mengetahui atau mempelajarinya. Menurut Nurhasanah \& Sobandi, (2016) ada beberapa indikator minat belajar yaitu perasaan senang, ketertarikan, perhatian, keterlibatan mahasiswa.

\section{METODE}

Penelitian ini merupakan jenis penelitian kuantitatif, yang dimana penelitian disini data yang diperoleh berbentuk angka-angka yang menggunakan teknik analisis statistik. Pada penelitian ini peneliti menggunakan rancangan penelitian ex-post facto. Penelitian ex-post facto adalah penelitian dimana peneliti berhubungan dengan variabel yang telah terjadi dan tidak perlu memberikan perlakuan terhadap variabel yang telah diteliti (Wilda et al., 2017). Hal ini 
sependapat dengan (Muliadi, 2020) penelitian ex-post facto adalah untuk meneliti hubungan sebab akibat yang tidak dimanipulasi atau tidak diberikan perlakuan oleh peneliti, tetapi hanya merekam data dari kegiatan yang telah terjadi.

\section{Uji Validitas}

Uji validitas dimaksudkan untuk mengetahui sejauh mana keakuratan dan ketelitian antara hasil pengukuran dari variabel yang diteliti dibandingkan dengan teori yang ada. Validitas menggambarkan bagaimana kuesioner sungguh-sungguh mengukur apa yang akan diukur. Sehingga, dapat dikatakan bahwa semakin tinggi validitas suatu tes, maka alat yang digunakan untuk melakukan tes tersebut semakin tepat mengenai sasarannya (Heryanto, 2015). Uji validitas dilakukan dengan cara membandingkan angka $r$-hitung dengan $r$-tabel dengan rumus sebagai berikut:

$r_{x y}=\frac{N \sum X Y-\left(\sum X\right)\left(\sum Y\right)}{\sqrt{\left\{\left(N \sum X^{2}-\left(\sum X\right)^{2}\right\}-\left\{N \sum Y^{2}-\left(\sum Y\right)^{2}\right)\right\}}}$

Keterangan:

$r_{x y} \quad$ : Nilai koefisien korelasi product

$N \quad$ : Banyaknya responden

$\sum X \quad$ : Total skor pernyataan variabel $\mathrm{x}$

$\sum Y \quad$ : Total skor pernyatan variabel $\mathrm{y}$

$\sum X^{2} \quad$ : Kuadrat skor pernyataan variabel $\mathrm{X}$

$\sum Y^{2} \quad$ : Kuadrat skor pernyatan variabel $\mathrm{Y}$

$\sum X Y \quad$ : Hasil perkalian dari skor jumlah variabel $\mathrm{X}$ dan $\mathrm{Y}$

\section{Uji Reabilitas}

Uji reabilitas adalah tingkat kepercayaan terhadap hasil suatu pengukuran. Pengukuran yang memiliki reabilitas tinggi merupakan pengukuran yang mampu memberikan hasil ukur terpercaya (reliable). Reabilitas disebut juga sebagai keterpercayaan, keterendahan, konsistensi atau kestabilan (Heryanto, 2015). Dalam pengujian reabilitas dilakukan dengan menggunakan teknik alpha cronbach yang rumusnya sebagai berikut:

$r_{11}=\left(\frac{k}{k-1}\right)\left(1-\frac{\sum \sigma_{b=}}{\sigma_{z}^{2}}\right)$

Keterangan: 


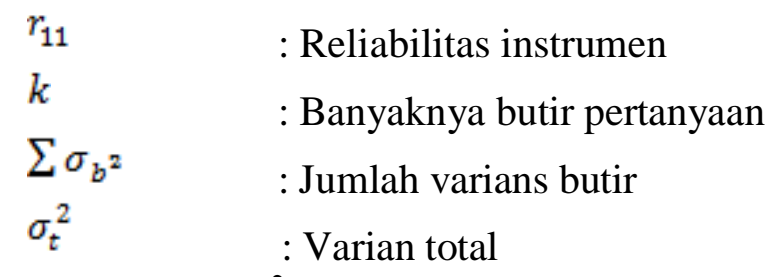

\section{Chi square $\left(\mathrm{X}^{2}\right)$}

Chi square atau chi kuadrat adalah pengujian hipotesis mengenai perbandingan antara frekuensi observasi atau yang benar-benar terjadi dengan frekuensi harapan atau ekspetasi. Adapun rumus yang digunakan chi square $\left(\mathrm{X}^{2}\right)$ untuk menganalisa data hasil penelitian ini adalah chi square corelation $2 \times 2$ dengan rumus dan rincian langkah menggunakan rumus chi square adalah sebagai berikut:

$$
\begin{aligned}
X^{2}=\sum_{i-1}^{\mathrm{K}}\left(\frac{f_{0}-f_{h}}{f_{h}}\right) 2 \\
\text { Keterangan: } \\
X^{2} \quad: \text { Chi kuadrat } \\
f_{0} \quad: \text { Frekuensi yang diobservasi } \\
f_{h} \quad: \text { Frekuensi yang diharapan } \\
\mathrm{K} \quad: \text { Banyaknya kategori }
\end{aligned}
$$

Setelah nilai frekuensi observasi diketahui, selanjutnya mencari besarnya frekuensi harapan $(\mathrm{Fe})$ dengan rumus sebagai berikut:

$$
\mathrm{Fe}=\frac{\sum \text { Frekuensi Sebaris } X \sum \text { Frekuensi Sekolom }}{\mathrm{N}}
$$

\section{Contingency Coefficient (C)}

Contingency Coefficient atau yang disebut dengan koefisien kontingensi adalah antara dua variabel yang berskala data nominal. Fungsinya adalah untuk mengetahui asosiasi atau relasi antara dua perangkat atribut. Contingency Coefficient sangatlah erat kaitannya dengan chi square sebab berdasarkan rumus uji koefisien, bahwa tidaklah mungkin koefisien ini dapat dihitung tanpa terlebih dahulu mengetahui nilai dari chi square. Chi square digunakan untuk menguji hipotesis komparatif K sample. Adapun rumus yang digunakan adalah:

$$
\mathrm{Kk}=\frac{\sqrt{X 2}}{X^{2}+N}
$$

Keterangan:

$\mathrm{Kk}$

: Koefisien kontingensi 
Setelah hasil nilai koefisien kontingensi diketahui dan dikonsultasikan dengan tabel interpretasi koefisien korelasi:

Tabel Interpretasi Koefisien Korelasi

\begin{tabular}{|c|c|c|}
\hline No & Nilai & Interpretasi \\
\hline 1 & $\pm 0,00$ s.d $\pm 0,20$ & Tidak ada korelasi/pengaruh \\
\hline 2 & $\pm 0,21$ s.d $\pm 0,40$ & Korelasi rendah \\
\hline 3 & $\pm 0,41$ s.d $\pm 0,60$ & Korelasi sedang \\
\hline 4 & $\pm 0,61$ s.d $\pm 0,80$ & Korelasi tinggi \\
\hline 5 & $\pm 0,81$ s.d $\pm 1,00$ & Korelasi sempurna \\
\hline
\end{tabular}

\section{HASIL DAN PEMBAHASAN}

\section{Pengaruh Pembelajaran Daring dan Luring Terhadap Minat Belajar Mahasiswa}

Untuk hasil analisis mayor pada penelitan ini menunjukkan bahwa tidak ada pengaruh antara pembelajaran daring dan luring terhadap minat belajar. Hal ini dibuktikan dari hasil analisis yang menggunakan korelasi product moment untuk membuktikan hipotesa kerja mayor diperoleh nilai koefisien korelasi sebesar 0,17. Yang apabila dikonsultasikan dengan tabel interpretasi maka nilai 0,17 terletak antara $\pm 0,00$ s.d $\pm 0,20$ maka tingkat korelasi antara pengaruh pembelajaran daring dan luring terhadap minat belajar mahasiswa ialah tidak ada korelasi.

Untuk mengetahui apakah hipotesis diterima atau ditolak, maka harga chi square dibandingkan dengan harga kritik chi square. Hasil pengujian hipotesis selengkapnya adalah sebagai berikut: harga $r_{\text {tabel }}\left(\mathrm{X}_{1}\right)$ dengan derajat kebebasan $(\mathrm{db})=1$ pada tabel taraf signifikansi $5 \%=3,841$. Sedangkan harga $\mathrm{r}_{\text {hitung }}$ sebesar $=$ 1,6566. Jadi harga $r_{\text {hitung }} 1,6566<$ harga $r_{\text {tabel }} 3,841$, jadi $r_{\text {hitung }}$ lebih kecil dari $r_{\text {tabel }}$ yang artinya hipotesis nihil (Ho) ditolak dan hipotesis kerja (Ha) diterima, berarti "Tidak ada pengaruh pembelajaran daring dan luring terhadap minat belajar mahasiswa pada masa pandemi covid-19". 
Dari hasil analisis tersebut yang dominan memberikan pengaruh terhadap minat belajar adalah pembelajaran luring apabila dibandingkan dengan pembelajaran daring.

\section{Pengaruh Pembelajaran Daring Terhadap Minat Beajar Mahasiswa}

Untuk hasil analisis minor pertama pada penelitan ini menunjukkan bahwa tidak ada pengaruh antara pembelajaran daring terhadap minat belajar. Hal ini dibuktikan dari hasil uji signifikansi antara pembelajaran daring terhadap minat belajar mahasiswa yang diperoleh hasil $r_{\text {hitung }}$ 0,0232 dan taraf signifikansi $5 \%=$ 3,841. Hal ini dibuktikan dari hasil analisis yang menggunakan korelasi product moment untuk membuktikan hipotesa kerja minor diperoleh koefisien korelasi sebesar 0,02 apabila dikonsultasikan dengan tabel interpretasi maka nilai 0,02 terletak antara $\pm 0,00$ s.d $\pm 0,20$ maka tingkat korelasi antara pengaruh pembelajaran daring terhadap minat belajar mahasiswa ialah tidak ada korelasi.

Untuk mengetahui apakah hipotesis diterima atau ditolak, maka harga chi square dibandingkan dengan harga kritik chi square. Hasil pengujian hipotesis selengkapnya adalah sebagai berikut: harga $\mathrm{r}_{\text {tabel }}\left(\mathrm{X}_{2}\right)$ dengan derajat kebebasan $(\mathrm{db})=1$. Jadi harga $\mathrm{r}_{\text {hitung }} 0,0232<$ harga $\mathrm{r}_{\text {tabel }} 3,841$ yang artinya $\mathrm{r}_{\text {hitung }}$ lebih kecil dari $r_{\text {tabel }}$ yang berarti "Tidak ada pengaruh pembelajaran daring terhadap minat belajar mahasiswa".

Hasil penelitian ini tidak sesuai dengan beberapa pendapat para ahli yang diantaranya (Susanti, 2020) yang mengemukakan bahwa pembelajaran daring secara keseluruhan mahasiswa akan puas dengan pembelajaran yang fleksibel tidak terkendala waktu dan tempat. Sedangkan hasil dari penelitian ini, bahwasanya tidak ada pengaruh pembelajaran daring terhadap minat belajar mahasiswa dikarenakan banyak kendala diantaranya seperti mahasiswa kurang paham dengan penjelasan dosen disaat dosen menjelaskan materi, terbatasnya kuota internet dan kurangnya sinyal membuat mahasiswa kurang minat belajar dalam pembelajaran daring.

\section{Pengaruh Pembelajaran Luring Terhadap Minat Belajar Mahasiswa}

Untuk hasil analisis minor kedua pada penelitan ini menunjukkan bahwa terdapat pengaruh antara pembelajaran luring terhadap minat belajar. Hal ini dibuktikan dari hasil uji signifikansi antara pembelajran luring terhadap minat 
belajar mahasiswa yang diperoleh hasil $\mathrm{r}_{\text {hitung }}$ 14,2734 dan taraf signifikansi $5 \%=$ 3,841. Hal ini dibuktikandari hasil analisis yang menggunakan korelasi product moment untuk membuktikan hipotesa kerja minor diperoleh koefisien korelasi sebesar 0,45 apabila dikonsultasikan dengan tabel interpretasi maka nilai 0,45 terletak antara $\pm 0,41$ s.d $\pm 0,60$ maka tingkat korelasi antara pengaruh pembelajaran luring terhadap minat belajar mahasiswa ialah korelasi sedang.

Untuk mengetahui apakah hipotesa diterima atau ditolak, maka harga chi square dibandingkan dengan harga kritik chi square. Hasil pengujian hipotesa selengkapnya adalah sebagai berikut: harga $\mathrm{r}_{\text {tabel }}\left(\mathrm{X}_{2}\right)$ dengan derajat kebebasan $(\mathrm{db})=1$. Jadi harga $r_{\text {hitung }} 14,2734>$ harga $r_{\text {tabel }}$ 3,841 yang artinya $r_{\text {hitung }}$ lebih besar dari $r_{\text {tabel }}$ yang berarti "Ada pengaruh pembelajaran luring terhadap minat belajar mahasiswa".

Hasil penelitian ini sesuai dengan beberapa pendapat para ahli yang diantaranya, menurut (Rosita \& Leonard, 2015) bahwasanya pembelajaran luring, mahasiswa lebih paham dan mengerti dengan penjelasan dosen.

\section{KESIMPULAN}

Berdasarkan hasil penelitian dan analisis data yang telah dilakukan oleh peneliti melalui pemberian angket kepada mahasiswa tentang pengaruh pembelajaran daring dan luring terhadap minat belajar mahasiswa pada masa pandemi covid-19 prodi pendidikan ekonomi semester genap tahun akademi 2020/2021, maka penulis dapat mengambil kesimpulan sebagai berikut:

\section{Kesimpulan Mayor.}

Tidak ada pengaruh pembelajaran daring dan luring terhadap minat belajar mahasiswa pada masa pandemi covid-19 prodi pendidikan ekonomi semester genap tahun akademi 2020/2021 sebesar 0,17 dengan tingkat pengaruh tidak korelasi.

2. Kesimpulan Minor

a. Tidak ada pengaruh pembelajaran daring terhadap minat belajar mahasiswa pada masa pandemi covid-19 prodi pendidikan ekonomi semester genap tahun akademi 2020/2021 sebesar 0,02 dengan tingkat pengaruh tidak ada korelasi. 
b. Ada pengaruh pembelajaran luring terhadap minat belajar mahasiswa pada masa pandemi covid-19 prodi pendidikan ekonomi semester genap tahun akademi 2020/2021 sebesar 0,45 dengan tingkat pengaruh sedang.

\section{DAFTAR RUJUKAN}

Ah, H. F., Arief, Z. A., \& Muhyani, M. (2019). Strategi Motivasi Belajar Dan Minat Belajar Dengan Hasil Belajar Bahasa Arab. Tawazun: Jurnal Pendidikan Islam, 12(1), 112-127. https://doi.org/10.32832/tawazun.v12i1.1843

Heryanto, I. (2015). Analisis pengaruh produk, harga, distribusi, dan promosi terhadap keputusan pembelian serta implikasinya pada kepuasan pelanggan. Jurnal Ekonomi, Bisnis \& Entrepreneurship, 9(2), 80-101. https://doi.org/2443-2121Heryanto, I. (2015). Analisis pengaruh produk, harga, distribusi, dan promosi terhadap keputusan pembelian serta implikasinya pada kepuasan pelanggan. Ekonomi, Bisnis \& Entrepreneurship, 9(2), 80-101. http://doi.org/2443-2121

Jaelani, A. (2015). Pembelajaran Kooperatif, Sebagai Salah Satu Model Pembelajaran Di Madrasah Ibtidaiyya (Mi). Al Ibtida: Jurnal Pendidikan Guru MI, 2(1), 1-16. https://doi.org/10.24235/al.ibtida.snj.v2i1.189

Lestari, I. (2015). PENGARUH WAKTU BELAJAR DAN MINAT BELAJAR TERHADAP HASIL BELAJAR MATEMATKA. Jurnal Formatif, 3(2), $115-125$.

Malyana, A. (2020). Pelaksanaan Pembelajaran Daring dan Luring Dengan Metode Bimbingan Berkelanjutan Pada Guru Sekolah Dasar Di Teluk Betung Utara Bandar Lampung. Jurnal Ilmiah Pendidikan Dasar Indonesia, 2(1), 67-76.

Muliadi, A. (2020). Perbedaan Gender Dalam Sikap Entrepreneur Mahasiswa Pendidikan Biologi. Jurnal Ilmiah Mandala Education, 6(2), 1329-1334.

Munirah, Sumyati, S., \& Putri, A. (2018). Pengaruh Kecerdasan Emosional Terhadap Hasil Belajar Matematika Peserta Didik. AULADUNA: Jurnal Pendidikan Dasar Islam, 5(2), 138-145. https://doi.org/10.24252/auladuna.v5i2a2.2018

Nurhasanah, S., \& Sobandi, A. (2016). Minat Belajar Sebagai Determinan Hasil Belajar Siswa (Leraning Interest as Determinant Student Learning Outcomes). Jurnal Pendidikan Manajemen Perkantoran, 1(1), 128-135. https://doi.org/10.17509/jpm.v1i1.3264

Pane, A., \& Dasopang, M. D. (2017). Belajar Dan Pembelajaran. FITRAH:Jurnal Kajian Ilmu-Ilmu Keislaman, 333. https://doi.org/10.24952/fitrah.v3i2.945

Rofiq, M. N. (2010). Pembelajaran Kooperatif (Cooperative Learning) Dalam Pengajaran Pendidikan Agama Islam. Jurnal Falasifa, 1(1), 1-14.

Rosita, I., \& Leonard. (2015). Meningkatkan Kerja Sama Siswa Melalui Pembelajaran Kooperatif Tipe Think Pair Share. Formatif: Jurnal Ilmiah Pendidikan MIPA, 3(1), 1-10. https://doi.org/10.30998/formatif.v3i1.108

Setyaningsih, K. D. (2020). Analisis Pelaksanaan Pembelajaran Jarak Jauh Di Sd Negeri Karangrena 03. Jurnal Riset Pendidikan Dasar (JRPD), 1(2), 19-27. https://doi.org/10.30595/.v1i2.9012 
Sijabat, A., Sianipar, H. S., \& Siahaan, T. M. (2020). Pengaruh Pembelajaran Daring Terhadap Minat Belajar Mahasiswa Pendidikan Fisika Uhkbpnp Pada Matakuliah Fisika Umum. 2(1), 84-88.

Susanti, F. A. (2020). Upaya Peningkatan Hasil Belajar Dan Minat Belajar Melalui Model Examples Non Examples Pada Pembelajaran Daring Peserta Didik Kelas IV SD Negeri Keblukan Tahun Pelajaran 2020/2021. JP3 (Jurnal Pendidikan Dan Profesi Pendidik), 6(1), 1-12. https://doi.org/10.26877/jp3.v6i1.7283

Syarifudin, A. S. (2020). Impelementasi Pembelajaran Daring Untuk Meningkatkan Mutu Pendidikan Sebagai Dampak Diterapkannya Social Distancing. Jurnal Pendidikan Bahasa Dan Sastra Indonesia Metalingua, 5(1), 31-34. https://doi.org/10.21107/metalingua.v5i1.7072

Waruwu, marinus. (2020). STUDI EVALUATIF IMPLEMENTASI PEMBELAJARAN DARING SELAMA PANDEMI COVID-19. JURNAL ADMINISTRASI PENDIDIKAN, 27(2), 288-295.

Wilda, Salwah, \& Ekawati, S. (2017). Pengaruh kreativitas dan minat belajar terhadap hasil belajar matematika siswa. Pedagogy: Jurnal Pendidikan Matematika, 2(1), 134-160. 